\title{
A Study on Advertisement and Efficiency in Indian Advertisement Industries
}

\author{
Siddhant Vasantrao Wadmare
}

\begin{abstract}
Advertising could be a powerful communication force and important selling tool serving to to sell goods, services, images, and ideas through channel of knowledge and persuasion. It is highly visible force within the society. All people receive several advertising messages daily. It is essential to the success of any sort of business and business. Non-business organization like government, school and universities, and Public Service teams employ a lot of and a lot of advertising ways. It's one of the elements of the selling and communication method. Advertising win over folks to shop for merchandise. All advertising contains each info and persuasion. Nowadays we are able to say advertising could be a communication, marketing, public-relation, info and persuasion method. This study is to look at however a client connects with promotional techniques utilized by advertising business in India. The advertising business in India is dynamic at a really quick pace. The promotional techniques that square measure currently being employed by the businesses is that specialize in a social cause and mistreatment folk as their whole representatives instead of mistreatment celebrity faces. Television, typically known as "king" of the advertising media has been perpetually facing challenges from not solely the digital medium, however conjointly from the web ads and social networking sites .In alternative words we are able to say that it's a complete psychological treatment of the buyer and a really artistic and exciting area also.
\end{abstract}

Key wards: Advertising; Print Media; Online Media; Advertising tips.

\section{INTRODUCTION}

Advertising could be a key a part of the sales method. Its role is to gather people commercialism a product with people who could also be fascinated by shopping for it. Itis important to recollect that potential customers are careful with their money. Seldom can they get one thing they do not need. Effective customer communication is an important a part of any business. Properly used, advertising will contribute to development and growth. Badly used, it is often a really pricey mistake. Advertisement serves a double purpose initial being the information all purpose that's, if shoppers are to extract the most satisfaction or utility from their restricted resources, then they have adequate flow of information concerning worth and potential performance of rival product and services. Second the persuasive purpose that's advertisements by various suggests that like enticing

Manuscript received on 30 March 2021 | Revised Manuscript received on 27 September 2021 | Manuscript Accepted on 15 October 2021 | Manuscript published on 30 October 2021.

* Correspondence Author

Siddhant Vasantrao Wadmare*, Dr. D. Y. Patil Arts Commerce and Science College Pimpri Pune (Maharashtra), India

(C) The Authors. Published by Lattice Science Publication (LSP). This is an open access article under the CC-BY-NC-ND license (http://creativecommons.org/licenses/by-nc-nd/4.0/) captions, slogans, characters, repetition etc influence shoppers to shop for their product. Advertising is one among the foremost fascinating disciplines within the era. It's a good communication tool that influences angle toward product, companies, whole names, lifestyles and public problems. Effective advertising refers to tell the general public regarding the correct product, at the correct time, through the correct medium. The correct media is that the crux of the success of the whole ad campaign. The main motive of this case study for different types of electronic and print media.

\section{ADVERTISEMENT}

\section{a) what is advertising?}

"Advertising is that the non personal communication of data usually obtained sometimes and typically and frequently persuasive in nature concerning merchandise, services or concepts by known sponsors through the varied media. Once a corporation or person makes product or provides a service, they must notice customers who can wish to shop for them. To succeed in giant numbers of potential customers they have to sell what they need made. If even a fraction of these people visit the shop and get one thing, this selling technique will pay for itself. A TV business is another example of advertising. It are often one amongst the foremost high-priced kinds of advertising, but it will reach tens of millions, or maybe many variant individuals. If a fraction of these viewers purchase the company's product or service, it is considered to be a winning campaign.

More cost-effective kinds of advertisements embody commercials on broadcast radio, signboard signs, and web content banner ads on the internet.

Good advertising should:

- Build the image of your business

- Justify the advantages of your merchandise and services

- Increase awareness of recent merchandise and services before, when and after they're launched

- Generate interest from your target market, also as a replacement audience of prospective customers

- Encourage customers to elicit info regarding your business and provide choices for the way they'll contact you

- Increase the demand from customers and increase your sales. Understanding the big selection of advertising ways offered can allow you to use the one that's best for your business. You'll realize that using a combination of ways provides you the strongest results.
Lattice Science Publication (LSP)

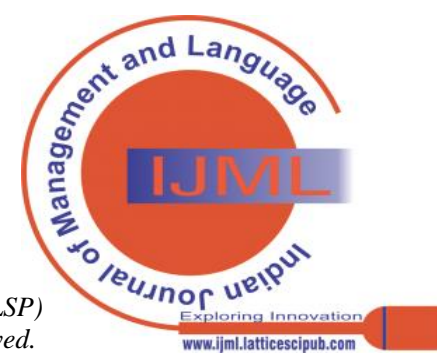




\section{A Study on Advertisement and Efficiency in Indian Advertisement Industries}

\section{B) Different types of advertising}

A productive movement can unfold the word concerning your products and services attract customers and generate sales. Whether or not you are trying to encourage new customers to shop for Associate in Nursing existing product or launching a brand new service, there ar several choices to decide on from. The most appropriate advertising possibility for your business can depend upon your audience and what the foremost price effective thanks to reach as many of them as attainable, as repeatedly as attainable. The advertising option chosen ought to conjointly replicate the proper surroundings for your product or service. For instance, if you recognize that your target market reads a particular magazine, you ought to advertise therein publication.

The following list is Associate in nursing introduction to advertising ways that you simply might use. Remember, you'll continually be artistic in your advertising to urge noticed (within advertising regulations).
A. Newspaper
B. Magazine
C. Radio
D. Television
E. Directories
F. Outdoor and transit
G. Direct mail, catalogues and leaflets
H. Leaflet marketing using letterbox drops and handouts
I. Online Advertising
J. Using social media to market your business

\section{TIPS FOR EFFECTIVE ADVERTISING}

Our words, sounds or reaction is important to your advertising success. Main aim for your advertising to:

- Be understood

- Stimulate action (such as a hunt or visit to your store)

- Accomplish outcome (such as a sale).

The following tips can assist you to satisfy these goals.

\section{Print Media}

Newspapers, magazines, directories, direct mail and billboards

- Use a headline with powerful expression or a unforgettable graphic to capture attention.

- Ensure graphics square measure prime quality in order that they look smart each in color and black and white.

- Don't use an excessive amount of text, as most readers can solely scan your advertisement for the key info.

\section{Electronic Media Television}

- Show the concept on the screen and back it up with a lot of info (e.g. a print advert or book delivered on to the viewer's home).

- Do not try to cram each product onto the screen - aim for an advertisement that's unforgettable, not overwhelming.

- Use skilled actors and voice artists instead of family and friends

\section{Radio}

- Keep it straightforward and do not attempt to several ideas in an exceedingly 30-second spot.

- Repeat the advantages of a product, the worth and also the name of your business thus listeners won't forget it.

- Use knowledgeable voice-over creator (or student) instead of making an attempt to do it yourself.

\section{Online Media}

- Have faith in what is going to work best online - do not simply take a print advertisement and transfer it. You will simply desire a headline and a hyperlink to your website.

- As reading onscreen isn't as straightforward as in print, certify your advertisement is clean and tidy.

- Use the language of your audience to stay them engaged

\section{CONCLUSION}

To conclude one would say that there's high impact of advertisement on public. This study clearly shows that there's high awareness among people on Advertising, It is a positive indication that we tend to area unit a socially aware society. An aware society can lead to being a far better society within the long haul. Not solely area unit people of this analysis area unit privy to Social Causes however are motivated and place in their efforts towards making a harmonious society.

\section{REFERENCE}

1. AashimaJain (Changing Face of Indian Advertisements.Studymode.Com. from http;//www.Studymode.Com/Essays/Changing-Face-Of-IndianAdver tisements1320582.Html

2. Advertising Principles, Problems and Cases: Charles J. Dirksen

3. Advertising: William. H.Bolen, John Wiley \& Sons Inc.,New York,1984

4. Advertising Agencies-Global and Indian Perspective: S. Shiva Ramu, Printwell, Jaipur, 1991

5. Advertising and Research: S.Ayaz Perrbhoy, Progressive, Bombay 1964.

6. Mass Communication in India:Keval. J. Kumar, Jaico Publishing House, Bombay, 1981

7. Ducoffe, R. H. (1996). Advertising Value and Advertising on the Web. Journal of Advertising Research.

\section{AUTHOR PROFILE}

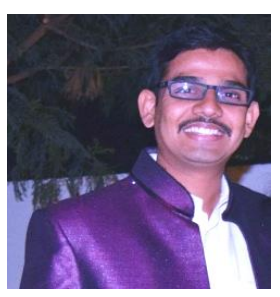

Mr. Siddhant Vasantrao Wadmare, has been working as a Director at DR.BABASAHEB AMBEDKAR PRATHISHTAN, E-Pic college of Animation-Gaming-Vfx, Beed 2007-2016. Suryadatta College of Management Information Research Technology Bavdhan Pune 2016-2018. He is still Working with DY Patil College of Art, Commerce \& Science Pimpri Pune. He has 14 years of full-time teaching experience and 5 years of visiting faculty experience. He has taught over 10Software at over 25 institutes all over Maharashtra with a combined experience of 25000 hours of Class room teaching. He is an approved Committee Member of Savitribai Phule Pune (SPPU) University (Syllabus). Also Member of Board of Studies at Yashvantrao Chavan Institute of Science, Satara (2018). Chairman S.Y. B.Sc. Animation SPPU Pune (2019-20). Judge for the "INTER-COLLEGIATE RESERCH PAPER PRESENTATION COMPETITION", (EXPLORE THE SCIENTIST IN YOU 2019) held at Dr. D.Y. Patil ACS College Pimpri Pune. Judge for the Face Panting \& T-shirt Panting Competition (CYGNUS 2019) held at Dr. D.Y. Patil ACS College Pimpri Pune.Judge for the Poster Competition (DEPARTMENT OF GEOGRAPHY) held at Dr. D.Y. Patil ACS College Pimpri Pune. Resource Person for State Level Conference held at Yashvantrao Chavan Institute of Science Satara (19 Jan 2019). Mr. Siddhant V. Wadmare has done M.Sc. Animation with 64.95\% from OPJS University and B.E (IT) with 67.93\% from Aurangabad University, Also done Diploma in 3D Animation \& Graphics with $90.00 \%$ from MSBTE Mumbai.

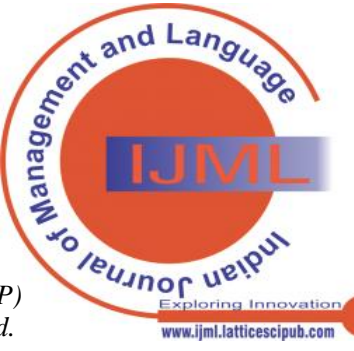


He is Pursuing PhD, (Motion Graphics) from OPJS University (2018-21) Mr. Siddhant V. Wadmare has Presented and Published 11 Research Papers in different National Conferences and Published by SURYA-THE ENERGY ISSN 24509162, Pune. Also Presented International Research Journal of Multi-Disciplinary Studies (UGC Approved) ISSN: 2454-8499 ,Recent Trend in the Field of Animation ( UGC Approval Journals),Rules of Issue of knowledge development with respect to Animation Industries ( UGC Approval Journals), Recent Trends in Animation World ( UGC Approval Journals) ,Impact of Animation in the Film Making ( UGC Approval Journals) ,Impact of Animation in Filed of TV Channel Industries Articles written by him have been published in various in house Magazines. Modern Trends Examination in VFX and SFX in the Animation Domain - ISSN 2249-8958 (Online), SCOPUS Indexed Journal. Animation Information Applications in the Capital Markets - ISSN 2278-0181. Modern Trends Examination in VFX and SFX in the Animation Domain - ISSN 2249-8958(Online), SCOPUS Indexed Journal. Animation Information in the Educational Sector. (National Conference at Dr. D. Y. Patil ACS College Pimpri Pune.) Metamorphosis Process of Animation and aesthetics to Arts ISSN2454-9150. Strictures of E-Learning in India Roll of Revolution in education- ISSN 2249-6661. A study on Advertisement and Efficiency in Indian Advertisement Industries- ISSN (Online) - 2582-6417. Mr. Siddhant V. Wadmare Get 5 Awards for his Knowledge for Different Platform "National Education Leadership Awards 2019 Phase II", KOLKATA. Institute of Scholars" InSc Young Achiever Award 2019"Bengaluru. "Global Teacher Role Model Award 2019",(Best Teacher Category) MVLA Trust's Mumbai (DEC 2019). "Golden Pixels Award 2020", (Best Teacher of the Year 2020) -VEDA Pune(FEB 2020). Outstanding Professor Award 2021",(Best Achievers Award 2021)- Magic Book of Record ( April 2021). Mr. Siddhant V. Wadmare has also attended several Seminars, Workshops, and Conferences organized by SPPU Pune. He has attended various training Programmers such as Students Development Programmers at Govt. Poly technique college Beed, Private College, Beed, Pune, Nanded, and Aurangabad.

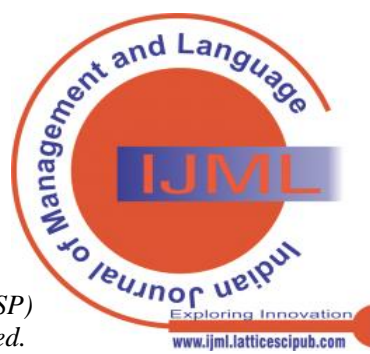

